\title{
URGENSI PELAKSANAAN TAHAPAN PERSIAPAN PENYUSUNAN KONTRAK OLEH PELAKU BISNIS DALAM MENGKONTRUKSI HUBUNGAN BISNIS
}

\author{
Isdian Anggraeny, Tongat, Wardah Dinnar Rahmadanti
}

\author{
Fakultas Hukum Universitas Muhammadiyah Malang \\ Jalan Raya Tlogomas Nomor 246, 65144, (0341) 464318, dan (0341) 460782 \\ Email : isdian@umm.ac.id, tongat@umm.ac.id
}

Fakultas Hukum Universitas Airlangga

Jl. Dharmawangsa Dalam Selatan, Airlangga, Kec. Gubeng, Kota SBY, Jawa Timur 60286, (031) 5023151

Email: wardahdinar@gmail.com

\begin{abstract}
Hypothetically-theoretical, almost certainly, without adequate understanding of the business relations agreement will not go well. So, every business person must understand the agreement. Departing from such needs, this article presents two fundamental issues as a material discussion. First, What are the elements that business people must consider in the preparation phase of the business contract? Secondly, What is the urgency of implementing a contract planning preparation phase by business people? Through normative and juridical studies, the explanation is obtained as follows. Business contracts are conducted through the following phases: Pre-contracted stages, contractual stages, and post-contractual phases. As an effort to make an ideal, systematic, and safe contract for the parties, it is necessary to maturation in the preparation phase of the contract drafting. The Implementation of the preparation phase of the business contract is very important so that the contract can be held accountable legally and can be understood by the parties.
\end{abstract}

Keywords: Contract planning, business people, business relationships

\begin{abstract}
ABSTRAK
Secara hipotetis-teoretis, hampir dapat dipastikan, tanpa ada pemahaman yang memadai tentang perjanjian hubungan bisnis tidak akan berjalan dengan baik. Sebegitu urgennya, maka setiap pelaku bisnis harus memahami tentang perjanjian. Berangkat dari kebutuhan yang demikian, tulisan ini menyajikan dua masalah pokok sebagai bahan pembahasan. Pertama, apa saja unsur-unsur yang harus diperhatikan oleh Pelaku Bisnis dalam tahapan persiapan kontrak bisnis? Kedua, apa urgensi pelaksanaan tahapan persiapan perancangan kontrak oleh Pelaku Bisnis? Melalui kajian secara yuridis normatif, diperoleh paparan penjelasan seperti berikut. Kontrak bisnis dilakukan melalui tahapan seperti berikut: tahapan pra kontratual, tahap kontraktual, dan tahap pasca-kontraktual. Sebagai upaya membuat kontrak yang ideal, sistematis, dan aman bagi para pihak maka perlu pematangan dalam tahap persiapan penyusunan kontrak. Pelaksanaan tahapan persiapan penyusunan kontrak bisnis sangat penting agar kontrak yang dibuat bisa dipertanggungjawabkan secara hukum dan dapat dipahami oleh para pihak.
\end{abstract}

Kata kunci : perancangan kontrak, pelaku bisnis, hubungan bisnis 


\section{PENDAHULUAN}

Berbisnis pada dasarnya adalah kegiatan yang menciptakan kerjasama antara para pihak untuk mendapatkan jaringan dan tentunya untuk memperoleh keuntungan. Apabila seseorang melakukan bisnis maka tidak akan luput dengan adanya hubungan bisnis yang didasari dengan aturan hukum. Hubungan bisnis merupakan suatu hubungan hukum dalam ruang lingkup kekayaan yang melibatkan dua orang/lebih yang saling memiliki kepentingan dan tujuan untuk saling mencari keuntungan satu sama lain.

Setiap manusia pada dasarnya memiliki kepentingan masing-masing dan saling membutuhkan satu sama lain. Sehingga untuk mewujudkan hal tersebut maka perlu diakomodir dalam suatu kontrak yang mampu memberikan kebutuhan tersebut.

Pemahaman dan keterampilan membuat suatu kontrak bisnis ini tentunya akan menunjang kegiatan bisnis/ usaha terutama untuk memberikan kepastian hukum dan perlindungan hukum apabila suatu saat timbul sengketa antar rekan bisnis maupun konsumen. Berkaitan dengan kenyataan ini, Yohanes Sogar Simamora berpendapat bahwa perjanjian merupakan salah satu bagian yang tidak dapat dipisahkan dari transaksi bisnis yang berfungsi untuk menjamin seluruh harapan yang dibentuk dari janji-janji para pihak dapat terlaksana dan terpenuhi. ${ }^{1}$ Dengan demikian, Kontrak bisnis merupakan langkah awal untuk melangkah bersama untuk mencapai tujuan bersama. Oleh karena itu, pentingnya kontrak bisnis guna membingkai secara hukum setiap proses bisnis yang dilakukan.

Istilah kontrak memiliki pengertian yang sama terhadap istilah perjanjian. Sebagaimana dijelaskan oleh Agus Yudha Hernoko dalam buku M. Natsir Asnawi bahwa pengertian perjanjian dan kontrak pada prinsipnya sama. Terdapat dua alasan yang mendasar terkait penjelasan tersebut, yaitu: 1) perspektif Burgerlijk Wetbook (BW) yang pada pokoknya tidak membedakan pemaknaan antara overeenkomst (perjanjian atau persetujuan) dengan contract (kontrak); 2) istilah perjanjian maupun kontrak sering digunakan dalam kontrak komersial. ${ }^{2}$

Pendapat berbeda diberikan oleh Subekti yang membedakan antara perjanjian dan kontrak. Perjanjian merupakan suatu peristiwa seorang berjanji kepada orang lain atau dua orang tersebut saling berjanji untuk melaksanakan suatu hal. Sedangkan kontrak merupakan perjanjian yang dibuat para pihak dalam bentuk tertulis.

Secara yuridis formal, definisi perjanjian terdapat pada Pasal 1313 KUHPerdata yang menyatakan bahwa "suatu persetujuan adalah

\footnotetext{
1 Simamora, Sogar, Yohanes. (2017) Hukum Kontrak: Prinsip-prinsip Hukum Kontrak Pengadaan Barang dan jasa Pemerintah di Indonesia. LaksBang Pressindo. Surabaya. Hlm. 25.

2 Asnawi, Natsir, Muhammad (2017), Aspek Hukum Janji Pra Kontrak, Yogyakarta: UII Press. Hlm 6
} 
suatu perbuatan di mana satu orang atau lebih mengikatkan diri terhadap satu orang atau lebih". Dengan demikian, perjanjian merupakan suatu perbuatan hukum. Perbuatan hukum tentunya akan melahirkan hubungan hukum yang berupa hak dan kewajiban para pihak yang terikat di dalamnya.

Pada hakikatnya, kontrak dimulai dari suatu perbedaan kepentingan dari para pihak yang melakukan perjanjian. Pertemuan kepentingan yang berbeda tersebut diselesaikan dengan cara negoisasi para pihak sehinga timbul suatu kesepakatan. Perjanjian pada hakikatnya merupakan alat untuk menjamin kepastian hukum para pihak dalam menunaikan kewajiban dan memenuhi hak masing-masing.

Selain itu, perjanjian dapat juga dijadikan alat untuk menyelesaikan sengketa bisnis yang timbul dari para pihak. Dengan demikian, perjanjian berfungsi alat untuk menjaga hubungan bisnis para pihak dan tolak ukur dalam menyelesaikan sengketa. Begitu pentingnya perjanjian bagi para pihak maka proses pembuatannya haruslah hati-hati. Pembuatan perjanjian haruslah didasarkan kepada ketentuan-ketentuan hukum, terutama hukum perjanjian yang diatur dalam Buku keIII KUHPerdata sehingga dapat menghindari terjadinya penyelesaian masalah hukum yang terkadang dapat melahirkan masalah hukum baru. ${ }^{3}$ Selain itu, menurut penulis perjanjian dalam hubungan bisnis selayaknya dilakukan secara tertulis sehingga fungsi perjanjian dapat berfungsi secara maksimal, terutama dalam hal pembuktian. Meskipun diketahui bahwa perjanjian menurut hukum perjanjian dapat dilakukan secara tulisan maupun lisan.

Perjanjian yang sah menurut hukum ialah perjanjian yang dibuat para pihak memenuhi syarat sah perjanjian yang tercantum pada Pasal 1320 KUHPerdata. Pasal 1320 KUHPerdata mengatur bahwa perjanjian yang sah harus memenuhi empat syarat, yaitu: kesepakatan, cakap untuk membuat kontrak, mengenai suatu hal tertentu, dan suatu sebab yang halal. Dengan memenuhi empat syarat tersebut, maka para pihak wajib terikat untuk melaksanakan prestasinya. Pengidentifikasian pemenuhan syarat-syarat sah perjanjian tersebut tentunya harus dilakukan di awal pembuatan kontrak/perjanjian atau pada tahapan persiapan perancangan kontrak. Dengan demikian para pihak sebelum bersepakat dalam kontrak telah memahami terlebih dahulu terhadap siapa ia telah melakukan kesepakatan dan mengetahui secara jelas causa dan obyek kesepakatan.

Berdasarkan uraian di atas maka dengan ini Penulis akan mengulas terkait urgensi pelaksanaan tahapan persiapan kontrak dalam mengkontruksi hubungan bisnis. Ulasan ini akan diawali dengan mengkaji secara teoritis terkait proses pembuatan perjanjian/kontrak

Artadi, I Ketut, (2010), Hukum Perjanjian Kedalam Perancangan Kontrak, Denpasar: Udayana University Press, Hlm 27 
dari aspek hukum perjanjian. Tulisan ini selanjutnya akan mediskusikan secara detail tahapan yang seharusnya penting diperhatikan oleh para pihak sebelum membuat kontrak. Oleh karena itu, penulisan ini akan mendeskripsikan, mengidentifikasi dan menganalisis dua pokok permasalahan. Pertama, apa saja unsur-unsur yang harus diperhatikan oleh Pelaku Bisnis dalam tahapan persiapan penyusunan kontrak? Kedua, apa urgensi pelaksanaan tahapan persiapan penyusunan kontrak oleh Pelaku Bisnis?

\section{PEMBAHASAN}

\section{Tahapan Persiapan Perancangan Kontrak oleh Pelaku Bisnis}

Hukum kontrak memberikan sarana yang memungkinkan kepada para pelaku bisnis untuk mengakomodasi selunuh kepentingannya. ${ }^{4}$ Kegiatan bisnis saat ini berkembang dengan adanya kesepakatan kedua belah pihak terhadap kontrak yang mereka buat. Hal ini tentu sejalan dengan asas kebebasan berkontrak yang tercantum di dalam Pasal 1338 (1) KUHPerdata. Menurut asas kebebasan berkontrak, setiap orang bebas membuat perjanjian, baik yang telah diatur atau belum diatur di dalam undang-undang. ${ }^{5}$
Kebebasan berkontrak memberikan peluang kepada setiap orang untuk membuat ketentuan hukum baru sesuai dengan kebutuhan mereka. Asas ini perlu dipahami bahwa: 1) hukum tidak dapat membatasi syarat-syarat yang boleh diperjanjikan oleh para pihak; 2) seseorang tidak boleh dipaksa untuk turut di dalam suatu perjanjian. ${ }^{6}$ Namun tentu saja, asas ini memiliki pembatasan yaitu ketentuan yang dibuat oleh para pihak tersebut tidak boleh bertentangan dengan undang-undang yang bersifat memaksa, kesusilaan, kepatutan, dan ketertiban umum. Asas kebebasan berkontrak ini tentu menyebabkan hukum kontrak kian berkembang. Namun, asas ini tidak berdiri sendiri karena dibatasi dengan asas lain seperti asas itikad baik, pacta sunt servanda, dan asas perikatan lainnya agar kontrak yang dibuat para pihak tidak melanggar ketentuan yang berlaku.

Selain itu, hukum kontrak kian berkembang mengikuti perkembangan ilmu pengetahuan dan teknologi yang semakin pesat. Agus Yudha Hernoko dalam buku Lukman Santoso Az menyatakan bahwa selain peran teknologi informasi dalam aktifitas bisnis sudah tidak dapat dinaifkan lagi, juga tipisnya tabir pemisah antara dua sistem

\footnotetext{
4 Simamora, Yohanes, Sogar, Op. Cit. Hlm 26

5 Hariri, Wawan, Muhwan, (2011), Hukum Perikatan (dilengkapi Hukum Perikatan dalam Islam) Bandung: CV Pustaka Setia, Hlm 137.

6 Anand, Ghansam, (2011, Mei-Agustus), Prinsip Kebebasan berkontrak dalam Penyusunan Kontrak, Yuridika, Volume 26, Nomor 2. HIm. 90.
} 
hukum besar, yaitu common law dan civil law dalam praktik hukum kontrak di Indonesia. ${ }^{7}$ Hal ini tentu saja menunjukan bahwa dinamika hubungan bisnis yang melibatkan pelaku bisnis antar sektor dan antar negara telah membawa dampak perkembangan hukum kontrak. $^{8}$

Seiring perkembangan hukum kontrak, setiap orang yang mengadakan hubungan bisnis selayaknya turut pula memperhatikan aspek hukum kontrak dalam membuat/menyusun kontrak bisnis. Pembuatan kontrak yang baik diperlukan adanya persiapan dan perencanaan terlebih dahulu. Pembuatan kontrak bisnis tentunya memiliki beberapa tahapan, yaitu tahap prakontraktual, tahap kontraktual, dan tahap pasca-kontraktual. ${ }^{9}$

Namun, sebelum masuk dalam proses penyusunan kontrak, sebaiknya Pelaku bisnis melakukan tahapan persiapan penyusunan Kontrak Bisnis. Tahapan ini dilakukan sebelum masuk pada Tahap Kontraktual. Dengan kata lain, para pihak mempersiapkan diri sebelum melalui proses penyusunan kontrak yaitu pada Tahap Prakontraktual. Sebelum mengidentifikasikan unsur-unsur yang harus diperhatikan oleh Pelaku Bisnis dalam tahapan persiapan Penyusunan Kontrak Bisnis, maka sebaiknya mengulas terlebih dahulu terkait proses penyusunan kontrak. Hal ini dilakukan agar dapat diidentifikasikan terlebih dahulu hal-hal yang dapat ditarik sebagai unsur-unsur yang dapat dipersiapkan dalam proses penyusunan kontrak oleh Pelaku Bisnis.

\section{Tahapan Penyusunan Kontrak Bisnis yang Ideal dan Sistematis}

Tahapan dalam pembuatan kontrak tergambar dari definisi kontrak yang dikemukakan oleh Van Dunne yang menyatakan bahwa kontrak merupakan hubungan hukum antara dua pihak atau lebih yang didasari dengan kata sepakat untuk menimbulkan akibat hukum. ${ }^{10}$ Berdasarkan definisi tersebut dapat diketahui bahwa proses dalam pembuatan kontrak meliputi tahap precontractual, tahap contractual, dan tahap postcontractual..$^{11}$

\section{a. Tahapan Precontractual (Prakontraktual)}

Tahap prakontraktual merupakan tahapan dimana para pihak melakukan penawaran dan penerimaan yang (negoisasi) dari para pihak yang kemudian dituangkan dalam kontrak. Hal ini dilakukan untuk mencapai kesepakatan dari para pihak terkait objek, hak dan kewajiban masingmasing pihak.

\footnotetext{
7 Az, Lukman, Santoso, (2016), Hukum Perikatan: Teori Hukum dan Teknis Pembuatan Kontrak, Kerjasama, dan Bisnis, Malang:Setara Press, hlm 2

8 Ibid, hlm. 2

9 Az, Lukman, Santoso, Op.Cit. hlm 90-94.

10 HS, Salim, et.al, (2014), Perancangan Kontrak \& Memorandum of Understanding (MoU), Jakarta:Sinar Grafika, hlm 8.

11 Asnawi, Natsir, Muhammad, Op.Cit., hlm 22
} 
Salah satu kegiatan pra kontrak dapat diwujudkan dengan pembuatan Memorandum of Understandin (MoU). $M o U$ tidak mengatur terkait sanksi yang tegas kepada pihak yang melanggar perjanjian, melainkan hanya berupa sanksi moral. Hal ini terjadi karena pembuatan MoU juga memperhatikan pasal 1338 KUH Perdata.

\section{b. Tahapan Contractual (kontraktual)}

Tahapan Contractual merupakan tahapan yang dilakukan setelah terjadi kesesuaian kehendak dari para pihak. Tahapan ini meliputi: menuangkan butir-butir kesepekatan para pihak pada draft kontrak, analisis draft kontrak, finalisasi draft kontrak yang dapat berupa kontrak dibawah tangan maupun otentik, dan penandatangan kontrak. Pola umum kontrak terdiri dari: Judul, Pembukaan, Komparisi (identitas para pihak), Premis (latar belakang kontrak), isi (klausula/pasal), penutup, dan lampiran (jika diperlukan).

Secara teoritis, struktur isi perjanjian terdapat tiga bagian, yaitu: bagian essentialia, bagian naturalia, dan bagian accidentalia. Selanjutnya, penjelasan bagian-bagian tersebut sebagai berikut:

1) Bagian Essensialia, merupakan bagian perjanjian yang harus ada di dalam dan tidak boleh diabaikan di dalam isi perjanjian. $^{12}$ Bagian essensialia meliputi para pihak, kata sepakat, objek tertentu, dan kausa halal. Bagian ini menjadi bagian pokok perjanjian yang dimasukan sebelum pasa-pasal. Misalnya terhadap perjanjian jual-beli, maka yang menjadi bagian essensialia adalah barang dan harga jual. Jika bagian esensialia ini tidak dipenuhi maka perjanjian ini menjadi batal.

2) Bagian Naturalia, merupakan bagian dari perjanjian yang memuat ketentuan hukum umum yang pada dasarnya sudah diatur didalam undang-undang. Walaupun bagian ini tidak dimuat dalam kontrak, maka perjanjian tetaplah syah. Namun, menurut Herlien Budiono alangkah lebih baik apabila ditegaskan di dalam kontrak. ${ }^{13}$ Misalnya, Aturan hukum perjanjian jual-beli yang diatur di dalam KUHPerdata seperti cara pembayaran, waktu pembayaran, dan tempat pembayaran.

3) Bagian Aksidentalia, merupakan bagian perjanjian yang memuat ketentuan khusus yang diperjanjikan oleh para pihak.

\footnotetext{
12 Budino, Herlien, (2013), Kumpulan Tulisan Hukum Perdata di Bidang Kenotariatan (Buku Kedua), Bandung: PT Citra Aditya Bakti, hlm 247.

13 Ibid, hlm 248.
} 
Bagian ini pula tidak harus ada di dalam perjanjian, namun akan menjadi kepastian terhadap kepentingan tertentu dengan maksud khusus dari para pihak. Misalnya, tempat penyerahan, domisili, dan pilihan hukum yang berlaku di dalam perjanjian. ${ }^{14}$

\section{c. Tahapan Postcontractual}

(Pascakontraktual)

Tahapan

Pascakontraktual merupakan tahapan pelaksanaan perjanjian dan penyelesaian sengketa (jika timbul sengketa). Pelaksanaan perjanjian ini merupakan suatu akibat hukum dari perjanjian yang telah disepakati dan memenuhi syarat sah perjanjian sebagaimana tercantum dalam Pasal 1320 KUHPerdata. Berdasarkan Pasal 1320 KUHPerdata, perjanjian yang sah adalah perjanjian yang memenuhi syarat berikut ini: kesepakatan, kecakapan, obyek tertentu, dan causa halal. Selain itu, kontrak yang disahkan para pihak mengimplementasikan asas pacta sunt servanda, yang mana kontrak tersebut mengikat seperti undang-undang bagi pembuatnya. Kontrak yang sudah disahkan harus dilaksanakan dengan landasan itikad baik.

\section{Unsur-unsur Yang Harus Diperhatikan Oleh Pelaku Bisnis Dalam} Tahapan Persiapan Penyusunan Kontrak Bisnis

Tahapan persiapan penyusunan kontrak diperlukan sejak proses negoisasi bisnis dimulai. Keberlakukan asas itikad baik sebagaimana yang tercantum di dalam Pasal 1338 KUHPerdata pun dimulai dari tahapan persiapan penyusunan kontrak. Terkait pemberlakuan asas itikad baik pada saat tahap pembuatan kontrak, apabila terjadi permasalahan di kemudian hari yang menimbulkan ketidakseimbangan atau melanggar rasa keadilan untuk masing-masing pihak maka hakim akan turut campur tangan. ${ }^{15}$

Tahapan persiapan penyusunan kontrak merupakan bagian dari tahapan prakontraktual. Sebagaimana telah dijelaskan pada proses penyusunan kontrak tersebut di atas, maka hal yang dapat menjadi perhatian Penulis yaitu pada tahap kontraktual. Hal ini guna memperoleh unsur-unsur yang seharusnya menjadi perhatian bagi masyarakat, khususnya pelaku bisnis, dalam menyusun kontrak. Pada tahapan ini, masyarakat terutama pelaku bisnis, telah dianggap mengetahui aturan hukum yang mendasari keabsahan perjanjian yang mereka buat.

Selain itu, hukum juga menganggap masyarakat mngetahui, memahami, dan

14 Ibid, hlm. 248.

15 Diputra, I Gusti, Agung Rio, (3 Desember 2018), Pelaksanaan Perancangan Kontrak dalam Pembuatan Struktur Kontrak Bisnis, Acta Comitas, Volumen 3, Nomor 3, Hlm. 557 
menyetujui subyek, obyek, dan isi dari kontrak tersebut. Oleh karena itu, masyarakat selaku pembuat dan pengguna kontrak dalam kegiatan bisnis maupun hubungan hukum lainnya perlu meningkatkan keterampilannya dalam membuat perjanjian sehingga tuntutan kebutuhan masyarakat akan kepastian hukum dari setiap kesepakatan bisnis atau kerjasama.

Berikut adalah unsur-unsur yang harus diperhatikan oleh pelaku bisnis dalam tahapan persiapan penyusunan kontrak bisnis, yaitu:

1) Mengenali dan memahami para pihak di dalam perjanjian

Mengenali dan memahami para pihak merupakan implikasi dari ketentuan Pasal 1320 (2) KUHPerdata yang menyatakan kecakapan merupakan salah satu syarat sah perjanjian. Kecakapan seseorang merupakan tolak ukur kewenangan bertindak seseorang dalam hukum. Pemangku atau pengemban hak dan kewajiban adalah subjek hukum dan sebab itu juga dari kacamata hukum memiliki kewenangan bertindak. ${ }^{16}$ Kecakapan seseorang menurut hukum diberikan oleh Undang-undang dakam bentuk ketentuan khusus. Misalnya, di dalam Pasal 39 (1) Undang-Undang Nomor 30 Tahun 2004 tentang Jabatan Notaris menyatakan bahwa Penghadap yang menghadap notaris ialah orang yang paling sedikit berumur 18 tahun atau telah menikah. Selain umur, kecakapan juga ditentukan bahwa orang tersebut tidak dibawah pengampuan.

Selain itu, mengenali dan memahami para pihak penting dalam menyusun komparisi yang mana komparisi di dalam perjanjian terdiri dari identitas para pihak, kedudukan dalam bertindak, dasar kedudukan, kecakapan dan kewenangan melaksanakan perbuatan hukum. Semua dasar kecakapan seseorang (manusia) dapat diketahui melalui identitas penduduk/identitas diri berupa Kartu Tanda Penduduk, Paspor, maupun identitas lainnya. Sedangkan untuk badan hukum dapat didasari dengan akta pendirian badan hukum sampai pada akta perubahannya.

2) Mengenali dan memahami obyek transaksi

Obyek Transaksi merupan unsur yang penting untuk diperhatikan terlebih dahulu oleh para pihak. Sebagaimana disebutkan di dalam Pasal 1320 (3) KUHPerdata, suatu hal tertentu (objek perjanjian) adalah apa yang menjadi kewajiban dari Debitur dan apa yang menjadi hak dari kreditur, hal ini pun sejalan dengan ketentuan Pasal 1332 1334 KUHPerdata. ${ }^{17}$

\footnotetext{
16 Budiono Herlin, (2014), Ajaran umum Hukum Perjanjian dan Penerapannya di Bidang Kenotariatan, Bandung: PT. Citra Aditya Bakti, hlm 102.

17 Ibid., hlm 108
} 
Menurut C. Asser-L.E.H. Rutten II dalam buku Herlien Budiono menyatakan bahwa untuk sahnya perjanjian maka objek perjanjian haruslah: dapat ditentukan, dapat diperdagangkan, mungkin dilakukan, dan/atau dapat dinilai dengan uang. ${ }^{18}$ Sri Dengan mengenali dan memahami Objek transaksi maka para pelaku bisnis dapat menentukan aturan hukum yang akan digunakan. Selain itu, para pelaku bisnis dapat secara detail dan rinci dalam menuangkan objek perjanjian ke dalam kontrak sehingga para pihak mengetahui secara jelas objek perjanjian yang dimaksud.

3) Memahami dan mengumpulkan bahan hukum berupa aturan perundangundangan dan dokumen hukum

Memahami dan mengumpulkan bahan hukum berupa aturan perundangundangan dan dokumen hukum merupakan satu hal yang memang seharusnya setiap Pelaku bisnis pahami sebelum membuat suatu kontrak bisnis. Hal ini mempengaruhi salah satu syarat sah perjanjian yang tercantum di dalam Pasal 1320 (4) KUHPerdata terkait causa halal yang jika tidak terpenuhi maka perjanjian/kontrak itu batal demi hukum.

Selain itu, dengan memahami dan mengumpulkan bahan hukum, maka para pelaku bisnis dapat menyusun isi kontrak dengan baik secara hukum dan berdasarkan proses bisnis yang runtut dan sistematis.

4) Memahami latar belakang kontrak dan garis besar transaksi

Latar belakang kontrak dan garis besar transaksi merupakan dasar penentuan Judul Kontrak dan Premis. Pengidentifikasian latar belakang kontrak dan garis besar transksi dapat pula membantu para pihak dalam penentuan aturan hukum yang berlaku bagi hubungan hukum yang akan mereka jalin. Hal ini dapat dilakukan dengan pembuatan Memorandum of Understanding (MoU) agar makin jelas terkait dengan keinginan para pihak.

5) Merumuskan pokok-pokok kontrak

Perumusan pokok-pokok kontrak harus dituangkan dalam klausul kontrak yang tersusun secara sistematis dan sesuai dengan proses bisnis. Perumusan ini sesuai dengan struktur isi perjanjian yang terdapat tiga bagian, yaitu: bagian essentialia, bagian naturalia, dan bagian accidentalia.

\section{Urgensi Pelaksanaan Tahapan Persiapan}

\section{Perancangan Kontrak Oleh Pelaku Bisnis}

Kontrak yang baik adalah kontrak yang memberikan kepastian hukum, keamanan, dan keuntungan bagi masing-masing Pihak (Pelaku Bisnis). Selain itu, kontrak yang 
dibuat oleh para pihak harus mampu mewujudkan rasa keadilan sehingga tidak ada pihak yang dibebani dalam pembuatan maupun pelaksanaan kontrak tersebut. Kegiatan bisnis merupakan kegiatan dari pelaku binsis yang sama-sama ingin mencari keuntungan. Selain itu, kegiatan bisnis pula memerlukan nilai anggaran yang cukup besar. Oleh karena itu perlu perhatian yang cukup agar tidak terjadi sengketa atau kelalaian dari para Pelaku Usaha. Dengan demikian, hukum kontrak haruslah menjadi bagian yang sangat penting untuk dipahami dan dilaksanakan oleh Para Pelaku Bisnis.

Seringkali, para Pelaku bisnis meremehkan kontrak bisnis yang mereka sepakati, seolaholah hanya simbolis terjalin kerjasama tanpa diidentifikasi terlebih dahulu bentuk kesepakatan mereka ke dalam kontrak. Padahal, setelah kontrak dibuat dan ditandatangani menimbulkan akibat hukum. Beberapa contoh bentuk perjanjian yang seringkali dibuat oleh para Pelaku Bisnis yaitu: Perjanjian Jual Beli;Perjanjian Sewa Me nyewa; Perjanjian Sewa Beli; Perjanjian Kontrak Kerja; Perjanjian Kerjasama; Perjanjian Borongan Pekerjaan; Perjanjian Utang Piutang; dan Perjanjian Jaminan Kebendaan.

Dengan demikian, penulis mengutarakan beberapa urgensi Pelaksanaan Tahapan Persiapan Perancangan Kontrak Oleh Pelaku Bisnis, yaitu sebagai berikut:
1) Para Pelaku bisnis dapat mengetahui cara dan metode penyusunan kontrak yang sistematis.

2) Para Pelaku bisnis dapat menyusun kontrak berdasarkan kaidah yang dapat diuji secara akademis dan praktis.

3) Memudahkan fungsi monitoring $\mathrm{dn}$ evaluasi substansi Kontrak karena susunan yang sistematis. Evaluasi substansi kontrak dapat dipetakan dalam beberapa pertanyaan, yaitu: 1) Apakah kontrak tersebut sudah dibuat sesuai dengan syarat sah perjanjian yang tercantum pada Pasal 1320 KUHPerdata?; 2) Apakah kontrak telah dibuat dlm fungsinya sebagai alat bukti yang dihadapan hukum?; 3) Apakah kontrak tidak melanggar ketentuan perundangundangan?4) Apakah kelengkapan kontrak telah dipenuhi (misalnya tanda tangan, materai, dan lain-lain)?

4) Pelaku Binsis dapat menuangkan proses bisnis ke dalam rumusan bahasa hukum yang tepat sehingga dapat dipahami oleh para pihak.

5) Kontrak yang dibuat oleh para pihak dapat dipertanggungjawabkan secara hukum dan dapat dipahami oleh para pihak selaku Pelaku Bisnis.

\section{KESIMPULAN}

1. Unsur-unsur yang harus diperhatikan oleh Pelaku Bisnis dalam tahapan persiapan penyusunan kontrak yaitu: Mengenali dan memahami para pihak di dalam 
perjanjian; Mengenali dan memahami obyek transaksi; Memahami dan mengumpulkan bahan hukum berupa aturan perundang-undangan dan dokumen hukum; Memahami latar belakang kontrak dan garis besar transaksi; dan Merumuskan pokok-pokok kontrak

2. Urgensi pelaksanaan tahapan persiapan penyusunan kontrak oleh Pelaku Bisnis, yaitu: para Pelaku bisnis dapat mengetahui cara dan metode penyusunan kontrak yang sistematis; Para Pelaku bisnis dapat menyusun kontrak berdasarkan kaidah yang dapat diuji secara akademis dan praktis; Memudahkan fungsi monitoring dan evaluasi substansi Kontrak; Pelaku Binsis dapat menuangkan proses bisnis ke dalam rumusan bahasa hukum yang tepat; dan Kontrak yang dibuat oleh para pihak dapat dipertanggungjawabkan secara hukum dan dapat dipahami oleh para pihak

\section{DAFTAR PUSTAKA}

\section{Peraturan Perundang-Undangan}

Kitab Undang-Undang Hukum Perdata

Undang-Undang Nomor 2 Tahun 2014 tentang Perubahan Undang-Undang Nomor 30 Tahun 2004 tentang jabatan Notaris

\section{Buku}

Asnawi, Muhammad, Natsir (2017), Aspek Hukum Janji Pra Kontrak, Yogyakarta: UII Press

Artadi, I Ketut, (2010), Hukum Perjanjian Kedalam Perancangan Kontrak, Denpasar: Udayana University Press.
Az, Lukman, Santoso, (2016), Hukum Perikatan: Teori Hukum dan Teknis Pembuatan Kontrak, Kerjasama, dan Bisnis, Malang:Setara Press.

Budino, Herlien, (2013), Kumpulan Tulisan Hukum Perdata di Bidang Kenotariatan (Buku Kedua), Bandung: PT Citra Aditya Bakti.

Budiono, Herlin, (2014), Ajaran umum Hukum Perjanjian dan Penerapannya di Bidang Kenotariatan, Bandung: PT. Citra Aditya Bakti, hlm 102.

Hariri, Wawan, Muhwan, (2011), Hukum Perikatan (dilengkapi Hukum Perikatan dalam Islam) Bandung: CV Pustaka Setia.

HS, Salim, et.al, (2014), Perancangan Kontrak \& Memorandum of Understanding $(M o U)$, Jakarta:Sinar Grafika.

Simamora, Yohanes, Sogar. (2017) Hukum Kontrak: Prinsip-prinsip Hukum Kontrak Pengadaan Barang dan jasa Pemerintah di Indonesia. LaksBang Pressindo. Surabaya.

\section{Jurnal}

Anand, Ghansam, (2011, Mei-Agustus), Prinsip Kebebasan berkontrak dalam Penyusunan Kontrak, Yuridika, Volume 26, Nomor 2

.Diputra, I Gusti, Agung Rio, (3 Desember 2018), Pelaksanaan Perancangan Kontrak dalam Pembuatan Struktur Kontrak Bisnis, Acta Comitas, Volumen 3, Nomor 3 